\title{
Supporting married girls: Calling attention to a neglected group
}

K.G. Santhya

Population Council

Annabel Erulkar

Population Council

Follow this and additional works at: https://knowledgecommons.popcouncil.org/departments_sbsr-pgy

Part of the Demography, Population, and Ecology Commons, Family, Life Course, and Society

Commons, Gender and Sexuality Commons, and the International Public Health Commons

How does access to this work benefit you? Let us know!

\section{Recommended Citation}

Santhya, K.G. and Annabel Erulkar. 2011. "Supporting married girls: Calling attention to a neglected group," Promoting Healthy, Safe, and Productive Transitions to Adulthood Brief no. 3. New York: Population Council. 


\section{Supporting married girls: Calling attention to a neglected group}

\section{Prepared by K.G. Santhya and Annabel Erulkar}

l $\mathrm{n}$ the next ten years, if current patterns continue, more than 100 million girls will marry before the age of 18 , according to Population Council analyses of United Nations country data. Child marriage-any marriage that occurs before the age of 18 -is considered a human rights violation by international convention.

Marriage transforms virtually all aspects of girls' lives. Typically, girls who marry are moved from their familial home and village, lose contact with friends, initiate sexual activity with someone they barely know, and soon become mothers. While existing data cannot definitively show causal links, the literature suggests that young age and/or young age at marriage may be independently correlated with low domestic authority, limited freedom of movement, and increased partner violence (Mason 1998; Jejeebhoy 2000; Kishor 2000; Kishor and Johnson 2004).

Recent Council studies add to this body of literature. In India, Santhya and colleagues use multivariate analysis to compare girls who married before age 18 to those who marry later. They find that girls who marry later are more likely to be involved in planning their marriage, have greater spousal interaction, and are less likely to have experienced physical violence or sexual violence (Santhya et al. 2010). Reproductive health indicators are similarly more positive for girls who marry later: girls who married later were more likely to have used a contraceptive to delay their first birth and to deliver their first baby in a health facility.

Married adolescents comprise the majority of sexually active adolescent girls in most developing countries. However, they tend to be overlooked by both adolescent sexual and reproductive health programs, which focus on unmarried girls, and reproductive health and development programs aimed at adult women.

Studies undertaken in a variety of settings reveal a range of characteristics common to married girls, including the following:

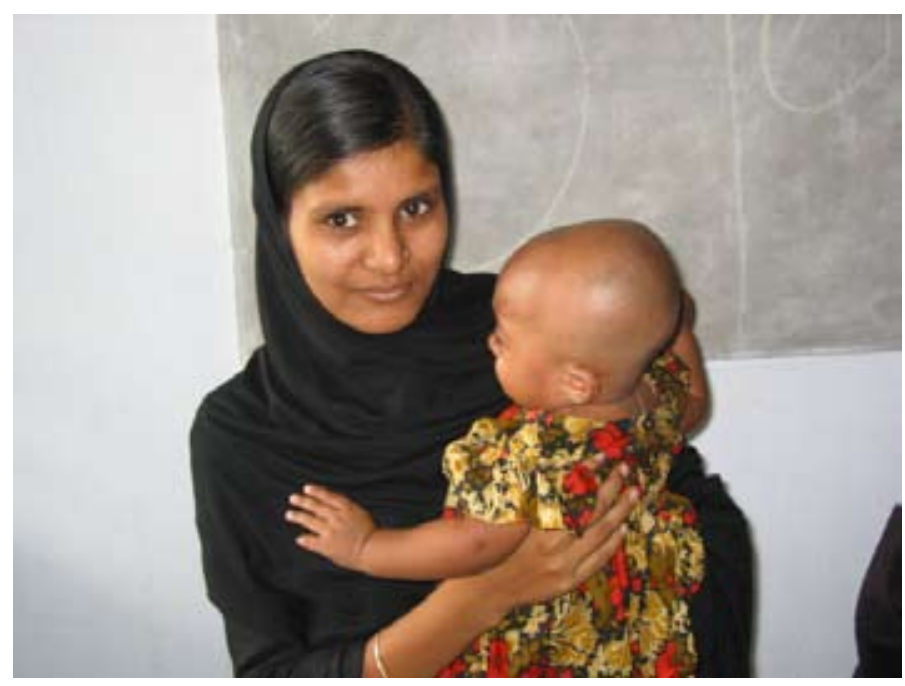

Young wives often find themselves with few friends, limited exposure to modern media, and less freedom of movement.

- Less social mobility/freedom of movement than unmarried girls their age (Amin, Mahmud, and Huq 2002), and compared to married women aged 20-34 (Santhya and Jejeebhoy 2003);

- Less access to modern media or other sources of information than unmarried girls their age (Amin, Mahmud, and Huq 2002; Thapa and Mishra 2003);

- Less autonomy and say in household and reproductive decisionmaking than married women aged 20-34 (Santhya and Jejeebhoy 2003);

- Increased risk of gender-based violence compared to women who marry later (Kishor and Johnson 2004; Santhya et al. 2010); 
- Uninformed and unprotected sexual relations with a husband who is likely to be considerably older-indeed, the younger the bride, the larger the age gap with her spouse (Clark, Bruce, and Dude 2006; Mensch, Bruce, and Greene 1998; Mensch 2005);

- Elevated risk of maternal and infant mortality for the youngest first-time mothers (those under 16 years) compared to young women who marry and initiate childbearing later (Miller and Lester 2003);

- Higher risk for sexually transmitted infections and HIV compared to unmarried sexually active girls (Clark 2004; Clark, Bruce, and Dude 2006).

\section{Meeting the needs of married girls}

In Bangladesh, India, Burkina Faso, Ethiopia, Nigeria, and elsewhere, the Population Council is undertaking research to better understand the situation of married girls and to more adequately meet their unique social, health, and development needs.

\section{First-time Parents Project, India}

The Population Council, in partnership with the Child In Need Institute (West Bengal) and Deepak Charitable Trust (Gujarat), implemented pilot interventions in Vadodara, Gujarat, and Diamond Harbour, West Bengal to reduce the social isolation of married adolescent girls, to improve their reproductive health, and to increase their ability to act in their own interest (Santhya et al. 2006). Researchers designed a quasi-experimental study with control and intervention groups and with surveys at baseline and endline. In-depth interviews and ongoing project monitoring were also carried out.

The interventions included: providing reproductive health information to married young women, their husbands, and influential adults in their families; making necessary adjustments in existing maternal and child health services; and empowering young women through group formation and other social networking activities. More than 1,800 young, newly married women who were pregnant or postpartum for the first time and more than 1,400 young husbands received reproductive health information.

The project mobilized over 1,000 girls into groups of roughly 8-12 members. The groups took a participatory learning approach and covered topics such as literacy, vocational skills, pregnancy and postpartum care, gender dynamics within and outside the family, and relationship issues. Girls identified ideas for activities, such as setting up a group savings account to cover emergency health expenses. In addition to meetings, the girls visited village administrative offices, banks, post offices, and organizations where women's groups are active. The girls worked together on development projects, celebrated common festivals, and organized welcome ceremonies for newly married members (Santhya et al. 2006).

The Council's evaluation of the project showed that the interventions had significant, positive effects on girls' autonomy, reproductive health knowledge and practice, and couple relations (Santhya et al. 2008). In both sites the project had a significant, independent effect on indicators reflecting married young women's autonomy, social support networks, partner communication and support, and knowledge of sexual and reproductive health. These indicators include the ability to make decisions regarding purchases of food, clothing, and other items; having friends in their village; partner support during family conflicts; and awareness of contraceptive methods and complications of pregnancy.

The study also assessed changes in reproductive health practices. Exposure to the project had a significant, positive net effect on such indicators as use of contraceptives to delay the first birth, obtaining comprehensive antenatal care, making delivery preparations, getting routine postpartum check-ups, and following recommended breastfeeding practices in one or both sites. Breastfeeding immediately after delivery, and feeding of colostrum, for example, increased dramatically in Diamond Harbour among participating girls and young women. The intervention did not, however, appear to positively influence a young woman's chances of delivering her first baby in a hospital or clinic in either site.

\section{Mères-éducatrices Project, Burkina Faso}

The Council, in partnership with the Burkina Faso Ministry of Social Action, the United Nations Population Fund (UNFPA), and a local nongovernmental organization (MWANGAZA), documented the lives of married adolescent girls in two rural regions of Burkina Faso and tested a pilot intervention to provide health and social support. The pilot intervention trained a group of respected young mothers from the community (known as mères-éducatrices) to visit married adolescent girls in their homes and provide health information on pregnancy and birth. Mères-éducatrices also provided vitamin $A$ and iron supplementation and often escorted girls to health centers for prenatal visits. The role of mères-éducatrices evolved and expanded over time: they served as resource persons for the community, led monthly health discussions, and sensitized health workers to the particular needs and vulnerabilities of young married girls.

From 2008-2010, the Council partnered with UNICEF, UNFPA, and the Ministry of Social Action to implement a pilot project entitled Eliminating early marriage in Burkina Faso: A plan for protection, reinforcement, and community action to understand the role of early marriage in the social and familial contexts in Burkina Faso. The goal of this project was to increase the human security of girls at-risk of marriage and those already married. Although the emphasis of this project was on delaying early marriage, married adolescent girls were also engaged in a leadership capacity as peer mentors, delivering reproductive health education to younger unmarried girls. Additionally, the project sought to increase married adolescent girls' financial assets by offering mères-éducatrices economic assistance to start income-generating activities (Engebretsen et al. 2011).

These mères-éducatrices projects demonstrate that locally recruited married adolescent girls as well as young mothers with special training 
can provide effective outreach to both girls and their families, and can, over time, facilitate girls' increased access to community resources. Further, in these traditional communities, mères-éducatrices are viewed as valuable assets (not as a cultural threat). With support from Ministry of Health agents, they disseminate health information, organize community discussions, and screen films on health topics such as sexually transmitted infections, HIVIAIDS, and female genital cutting. In this way, they have extended the reach of the regular service providers in the community.

\section{Delaying marriage and supporting married girls, Ethiopia}

In 2004, the Amhara Regional Bureau of Youth and Sports and the Population Council implemented a pilot project in Mosebo, a rural village in Ethiopia's Amhara region, to address the high level of child marriage in this area. In Amhara, $50 \%$ of girls are married by age 15 and $80 \%$ are married by age 18 (Erulkar et al. 2010). This pilot project developed into Berhane Hewan ("Light for Eve" in Amharic), a program targeting married and unmarried girls aged 10-19. Its overall goal is to establish appropriate and effective mechanisms to protect girls at risk of forced early marriage and support adolescent girls who are already married. Berhane Hewan includes four key components: group formation by adult female mentors, including groups for married girls; support for girls to remain in school, and participation in non-formal education; "community conversations," to engage the community in discussion of key issues related to early marriage; and the provision of an incentive or conditional cash transfer for families that keep girls unmarried and in school (Muthengi and Erulkar 2011).

While the primary focus of Berhane Hewan is to delay early marriage, building social, human, and economic assets of married girls is also an important aim of the program. Married program participants meet weekly to learn about reproductive health and ways to access family planning services (family planning is free at government facilities and the cost of a clinic card-20 birr, about US\$2.20-was supported by the project). Findings indicate that the program has led to concrete reproductive health improvements: at the end of the intervention, married girls in the intervention villages were almost three times as likely as girls from the control village to have used contraceptives. Additionally, Berhane Hewan has increased opportunities for married and unmarried girls to receive formal and informal education, and has provided livelihood skills such as agricultural techniques, poultry rearing, and construction of household items (Erulkar and Muthengi 2009). The success of this program provides a model for similar programs in Ethiopia and other rural settings where a large number of girls are married before age 15 .

\section{Areas for future work}

Council researchers are pursuing several initiatives to increase understanding of the transition to marriage (Amin and Bajracharya 2011), to expand married girls' opportunities, to increase their access to health services, and to develop appropriate health information messages, especially as related to first pregnancy and birth and to HIV and AIDS. They are implementing initiatives to delay age at marriage and are exploring when and how best to reach married girls' husbands in order to support married girls and improve their health and well being. It is also essential to develop specific protections and protocols for married adolescents, and to support young women in safely negotiating the transition to marriage in the context of the HIV epidemic.

\section{References and related publications}

Adhikari, R.K. 2003. "Early marriage and childbearing: Risks and consequences." In S. Bott, S. Jejeebhoy, I. Shah, and C. Puri (eds.), Towards Adulthood: Exploring the Sexual and Reproductive Health of Adolescents in South Asia. Geneva: World Health Organization.

Amin, Sajeda. 2004. "Child rights in Bangladesh," in Dina Siddiqy (ed.), Human Rights Report, Bangladesh, 2003. Dhaka: Ain O Shalish Kendra.

Amin, Sajeda and Ashish Bajracharya. 2011. "Assessing the costs of marriage: Marriage transactions in the developing world," Promoting Healthy, Safe, and Productive Transitions to Adulthood Brief No. 37. New York: Population Council.

Amin, Sajeda, Simeem Mahmud, and Lopita Huq. 2002. "Baseline survey report on rural adolescents in Bangladesh." Dhaka: Ministry of Women's Affairs, Government of Bangladesh.

Brady, Martha, Lydia Saloucou, and Erica Chong. 2007. "Girls' adolescence in Burkina Faso: A pivot point for social change." New York: Population Council.

Clark, Shelley. 2004. "Early marriage and HIV risks in sub-Saharan Africa," Studies in Family Planning 35(3): 149-160.

Clark, Shelley, Judith Bruce, and Annie Dude. 2006. "Protecting young women from HIVIAIDS: The case against child and adolescent marriage," International Family Planning Perspectives 32(2): 79-88.

Engebretsen, Sarah, Gisele Kabore, Martha Brady and Lydia Saloucou. 2011. "Addressing the needs of girls at-risk of early marriage and married adolescent girls in Burkina Faso," Promoting Healthy, Safe, and Productive Transitions to Adulthood Brief No. 9. New York: Population Council.

Erulkar, Annabel S., Ferede Abebaw, Worku Ambelu, et al. 2010. "Ethiopia gender survey: A study in seven regions," New York: Population Council.

Erulkar, Annabel, Tekle-Ab Mekbib, Negussie Simie, and Tsehai Gulema. 2004. The Experience of Adolescence in Rural Amhara Region, Ethiopia. Accra, Ghana: Population Council.

Erulkar, A.S. and E. Muthengi. 2009. "Evaluation of Berhane Hewan: A program to delay child marriage in rural Ethiopia," International Perspectices on Sexual and Reproductive Health 35(1): 6-14.

Haberland, Nicole, Erica Chong, and Hillary Bracken. 2003. "Married adolescents: An overview," Background paper prepared for WHO/UNFPA/Population Council Technical Consultation on Married Adolescents, Geneva, 9-12 December.

Jejeebhoy, Shireen. 2000. “Women's autonomy in rural India: Its dimensions, determinants, and the influence of context," in Harriet Presser and Gita Sen (eds.), Women's Empowerment and Demographic Processes: Moving Beyond Cairo. Oxford: Oxford University Press, pp. 204-238.

Kishor, Sunita. 2000. "Empowerment of women in Egypt and links to the survival and health of their infants," in Harriet Presser and Gita Sen (eds.), Women's Empowerment and Demographic Processes: Moving Beyond Cairo. Oxford: Oxford University Press, pp. 119-156. 
Kishor, Sunita and Kiersten Johnson. 2004. Profiling Domestic Violence: A MultiCountry Study. Calverton, MD: ORC Macro.

Mason, Karen Oppenheim. 1998. "Wives' economic decision-making power in the family: Five Asian countries," in Karen Oppenheim Mason, Noriko O. Tsuya, and Minja Kim Choe (eds.), The Changing Family in Comparative Perspective: Asia and the United States. Honolulu: East-West Center, pp. 105-133.

Mensch, Barbara. 2005. "The transition to marriage," in Cynthia B. Lloyd (ed.), Growing Up Global: The Changing Transitions to Adulthood in Developing Countries. Washington, DC: The National Academies Press, pp. 416-505.

Mensch, Barbara S., Judith Bruce, and Margaret E. Greene. 1998. The Uncharted Passage: Girls'Adolescence in the Developing World. New York: Population Council.

Miller, Suellen and Felicia Lester. 2003. "Meeting the needs of the youngest first-time mothers," draft background paper presented at WHO/UNFPA/ Population Council Technical Consultation on Married Adolescents, Geneva, 9-12 December.

Muthengi, Eunice and Annabel Erulkar. 2011. "Delaying early marriage among disadvantaged rural girls in Amhara, Ethiopia through social support, education and community awareness," Promoting Health, Safe, and Productive Transitions to Adulthood Brief No. 20. New York: Population Council.

Ram, F., R.K. Sinha, S.K. Mohanty, Arup Das, Aruna Lakhani, Nicole Haberland, and K.G. Santhya. 2006. Marriage and Motherhood: An Exploratory Study of the Social and Reproductive Health Status of Married Young Women in Gujarat and West Bengal, India. New Delhi: Population Council.
Santhya, K.G., U. Ram, R. Acharya, S.J. Jejeebhoy, et al. 2010. "Associations between early marriage and young women's marital and reproductive health outcomes: evidence from India." International Perspectices on Sexual and Reproductive Health 36(3): 132-139.

Santhya, K.G., N. Haberland, A. Das, et al. 2008. Empowering married young women and improving their sexual and reproductive health: Effects of the First-time Parents Project. New Delhi: Population Council.

Santhya, K.G., Nicole Haberland, Saswata Ghosh, et al. 2006. "Meeting the health and social needs of married girls in India: The First-time Parents Project's implementation and reach." Update. New Delhi: Population Council.

Santhya, K.G. and S. Jejeebhoy. 2003. "Sexual and reproductive health needs of married adolescent girls," Economic and Political Weekly 38(41): 4370-4377.

Suran, Luciana, Sajeda Amin, Lopita Huq, and Kobita Chowdury. 2004. "Does dowry improve life for brides? A test of the bequest theory of dowry in rural Bangladesh," Policy Research Division Working Paper no. 195. New York: Population Council.

Thapa, Shyam and Vinod Mishra. 2003. "Mass media exposure among youth in urban Nepal," Asia-Pacific Population Journal 18(1): 5-28.

\section{Donors}

In recent years, donors of the highlighted programs have included: Department for International Development (DFID), The William and Flora Hewlett Foundation, Japanese Government via the UN Trust Fund for Human Security, Andrew W. Mellon Foundation, The John D. and Catherine T. MacArthur Foundation, Nike Foundation, The Summit Foundation, United Nations Population Fund (UNFPA), and United Nations Foundation.

\section{(2) Population Council}

The Population Council changes the way the world thinks about critical health and development issues. We seek to understand the causes and consequences of gender inequality and the disparities in opportunity that arise during adolescence. We provide the evidence for better on-theground programs and policies that ensure successful and productive transitions to adulthood in developing countries. www.popcouncil.org

(C) 2011 The Population Council, Inc. 